\title{
Familial melanoma syndrome - phenotypic characterization and comparison with sporadic melanoma and healthy individuals - A Brazilian study
}

\author{
Moredo LF ${ }^{*}$, Soares de Sá BC ${ }^{1}$, de Ávila ALR ${ }^{1}$, Landman $\mathrm{G}^{2}$ and Duprat JP1 \\ ${ }^{1}$ Skin Cancer Department, A.C. Camargo Cancer Center, São Paulo, São Paulo, Brazil \\ ${ }^{2}$ Pathology Department, A.C. Camargo Cancer Center, São Paulo, São Paulo, Brazil
}

\begin{abstract}
Background: Multiple members affected (at the same branch) and/or multiple primary melanomas (2 or more) may characterize Familial Melanoma Syndrome (FMS).

Objectives: To characterize the phenotypic characteristics of three groups of patients, FMS, Sporadic Melanoma (SM) and healthy individuals (HI). And evaluate if there is a predominant phenotype on those with FMS or significant differences between the 3 groups assessed.

Methods: We included 59 individuals with FMS, 54 with sporadic melanoma and 74 healthy individuals. Characteristics evaluated: eye color and pigmentation on the iris, hair color, skin type (Fitzpatrick classification), freckles, atypical and total nevi count, history of sunburn, atypical mole syndrome (AMS).

Results: Concerning the germline mutation status on the $C D K N 2 A$ gene, association was not observed at the analyzed features. Familial Melanoma Syndrome patients had mostly dark eyes and hair, high-density freckles, less than 50 moles and phototype I or II. Phenotypic characteristics known to be related to higher melanoma risk were also prevalent on this group of patients, when compared with the two other groups - Sporadic melanoma and Healthy Individual: freckles in the lower arm $(p=0.026)$ and in the trunk $(p<0.001)$, great number of nevi $(p<0.001)$, AMS $(p<0.001)$, skin type I and II ( $<<0.001)$ and iris pigmentation $(p=0.008)$ History of sunburn was more frequently seen in SM patients ( $\mathrm{p}=0.050)$. Melanoma patients with AMS, phototype I or II and without history of sunburn have $98 \%$ of estimated probability to FMS.
\end{abstract}

Abbreviations: FMS: Familial melanoma syndrome; MPM: Multiple primary melanomas; SM: Sporadic melanoma; HI: Healthy individuals; CDKN2A: Cyclin dependent kinase inhibitor type 2A; AMS: Atypical mole syndrome; FM: Familial melanoma; CNS: Central nervous systems; CDK4: Cyclin dependent kinase 4; CM: Cutaneous melanoma.

\section{Introduction}

The Familial Melanoma Syndrome (FMS) can be characterized by families with multiple members affected with melanoma at the same branch of the family and patients with multiple primary melanomas (2 or more) [1,2]. Other cancers could be associated with the syndrome, such as pancreatic cancer and central nervous system (CNS) tumors. It is estimated that up to $10 \%$ of melanoma cases are in a familiar context [3].

Although many genes associated to familial melanoma have been described and can be tested nowadays, such as CDK4, BAP1, TERT, TERF2IP, CXC, ACD or POT1 [4] they represent less than $3 \%$ of all familial cases [4], the most studied and relevant is CDKN2A. Mutations on this gene has, so far, been found to confer a higher risk for developing melanoma and occurs in about 20 to $40 \%$ of familial melanoma cases [5-7]. Clinical risk factors associated to melanoma development are both environmental (mainly sun exposure) and phenotypical [8-10] being the phenotype the result from the expression of individual's genes and the interaction of these genes with environmental factors [11,12]. In association with personal and/or family history, phenotype plays an important role in melanoma development.

\section{Aims}

Although FMS has been broadly studied regarding genotype and phenotype, as well; data about Brazilian population are scarce. Furthermore, as CM could be the result of an interaction between genetic, environmental and behavior factors and, the risk for the development of the disease differs according to the geographic region, the study of specific populations becomes relevant $[7,13]$.

The purpose was to characterize the phenotype features of FM patients and analyze it regarding the CDKN2A mutation status, and also to compare phenotypic characteristics of this group with the same features assessed for sporadic melanoma patients and healthy individuals, trying to identify a predominant phenotype in the population clinically diagnosed with the FMS.

${ }^{\star}$ Correspondence to: Luciana Facure Moredo, Skin Cancer Department, A C Camargo Cancer Center. Rua Professor Antônio Prudente, 211, zip code 01509 900, Liberdade, São Paulo, São Paulo, Brazil, Tel: 55-11-21895135, E-mail lufacure@gmail.com

Received: October 25, 2020; Accepted: November 05, 2020; Published: November 12, 2020 


\section{Patients and methods}

Three groups were assessed on Skin Cancer Department at A.C. Camargo Cancer Center - São Paulo (Brazil). Group A- melanoma patients with FMS (from GenoMEL- Brazil study), group B- sporadic melanoma patients (SM), and group C- healthy individuals without family history of melanoma, pancreatic cancer or CNS tumor.

\section{Inclusion criteria}

FMS: multiple primary melanomas and/or $1 \mathrm{CM}$ and at least one familiar (1st or 2nd degree) with CM or pancreatic cancer or CNS tumor.

SM: only one melanoma by the time of informed consent signature, no family history of any cancer related to the syndrome.

Healthy individual: no personal or familiar history of cancer (melanoma, non-melanoma skin cancer, pancreatic cancer and CNS tumor).

\section{Phenotypic features}

Eye and hair color, phototype (Fitzpatrick), freckles density (from 0 to 100 , in 10 gradations according to density and proportion of each site covered - arms and shoulders $-0=$ no freckling; $20 / 40=$ low; $60 / 80 / 100=$ high), history of sunburn, iris pigmentation, total number of nevi, presence of clinically atypical nevi (diameter $\geq 5 \mathrm{~mm}$, when a papular component was present, the mole must have also a macular component; and at least two of the three: color variegated, contour uneven or border not well defined) and presence of AMS - according to Newton classification [14-17].

\section{Genetic studies}

Genetic sequencing was performed only in FMS group. Patients had DNA samples extracted from leukocytes. CDKN2A and CDK4 exons were amplified using $50 \mathrm{ng}$ of genomic DNA. Sequencing reactions were performed using Big Dye v.3.1 cycle sequencing kit on an ABI Prism 3500 genetic analyzer (Applied Biosystems). Details of genetic data were described in de Ávila, A.L.R. 2014 [18].

\section{Statistic analyses}

The baseline patient characteristics are expressed as absolute and relative frequencies for qualitative variables; and mean, median, standard deviation for quantitative variables. The chi-square or Fisher's tests were applied to evaluate the association between the phenotype characteristics and the study groups. For comparison of means among groups (HI, SM and FMS), the normality of distribution and homogeneity of variance of all continuous variables were assessed to determine the use of parametric or nonparametric tests. Additionally, in order to understand whether factors such as history of sunburn, phototype, AMS phenotype, eye and hair colour, freckles, iris pigmentation and nevi count affect patient's group the multinomial logistic regression model was fitted to data set. We fixed the significance level at 0.05. The software R, version 3.2.1 (www.r-project.org.br) was used for the analysis.

Ethical principles for medical research involving human subjects has been respected and followed according to the Declaration of Helsinki. The Ethics Committee of A C Camargo Cancer Center approved the study. Signed informed consent were obtained from all patients, and those with personal or family history of cancer presented pathology report by specialist, death certificate or physician letter to confirm the cancer.

\section{Results}

To evaluate if there is a predominant phenotype on those with FMS or significant differences between the 3 groups assessed, we included 59 patients on FMS group, 54 on Sporadic Melanoma and 74 healthy individuals.

\section{Main features of familial melanoma syndrome group}

On FMS group most of the patients had high-density freckles (61\%), phototype I or II (83\%), dark eyes and dark hair $(53 \%)$ and history of sunburn (66\%), while $58 \%$ of the individuals had less than 50 nevi. Mutation on $C D K N 2 A$ was observed on 8 patients.

Phenotypic characteristics related to CDKN2A mutation status on FMS group are described on Table 1. All patients carrying the mutation had phototype I or II; $75 \%$ had less than 50 common nevi, absence of AMS phenotype, brown eyes and dark hair. However, no statistical significance was observed associating the phenotypic characteristics and the mutational status for the analyzed features. Of 59 patients, $8(13.6 \%)$ carried the mutation. Clinical and molecular data from probands carrying mutations are described on Table 2.

\section{Familial melanoma, sporadic melanoma and healthy individual}

Phenotypic characteristics of Familial Melanoma Syndrome, Sporadic Melanoma and Healthy Individual are described on Table 3. Comparing the 3 groups, many features that increase the risk for developing melanoma $[19,20]$ were statistically significant and predominant on FMS group, such as: high density freckles in the lower arm and in the back ( $\mathrm{p}=0.026$ and $\mathrm{p}<0.001$, respectively), common nevi count $(\mathrm{p}<0.001)$, iris pigmentation $(\mathrm{p}=0.008)$, phototype I and II $(\mathrm{p}<0.001)$, presence of atypical nevi $(\mathrm{p}=0.006)$ and atypical mole syndrome $(\mathrm{p}<0.001)$. However, a positive sunburn history has been seen on $83 \%$ of patients with SM, followed by FMS individuals and HI, with $66 \%$ and $65 \%$, respectively. Iris pigmentation was observed more frequently on FMS group (34\%) curiously followed by Healthy Individual group (18\%) and SM group (11\%), p=0.008.

With the purpose of evaluating possible risk factors on individual characterization for FMS, multinomial regression model was adjusted.

Based on this regression model, the statistically significant variables that settled an estimated probability were AMS phenotype, phototype and history of sunburn (Table 4). This allowed us to determine that the patient with melanoma diagnosis, AMS, photype I or II and no history of sunburn presented $98 \%$ of estimated probability for FMS. For those with AMS, photype I or II and with history of sunburn this probability was $92.7 \%$. On the other hand, when they had no AMS, photype III or IV and history of sunburn the probability was only $4.4 \%$ (Table 5 ).

\section{Familial melanoma versus sporadic melanoma}

Data comparing familial melanoma (group A) and sporadic melanoma (group B) are shown on Table 6. We observed that patients have resembling characteristics, except for pigmentation on the iris, affecting $34 \%$ and $11 \%$ of individuals with FMS and SM, respectively $(\mathrm{p}=0.003)$ and AMS phenotype, presented on $39 \%$ of the FMS and $4 \%$ of the SM group $(\mathrm{p}<0.001)$.

FMS group had a younger mean age at diagnosis (46 years vs 51 years $\mathrm{p}=0,034$ ), with $61 \%$ of patients younger than 50 years compared with $41 \%$ of SM group. 
Moredo LF (2020) Familial melanoma syndrome - phenotypic characterization and comparison with sporadic melanoma and healthy individuals - A Brazilian study

Table 1. Phenotypic characteristics related to the CDKN2A mutation status on FMS group $(n=59)^{1}$ The red hair patient was excluded from this analyses

\begin{tabular}{|c|c|c|c|c|c|}
\hline \multirow[t]{2}{*}{ Variables } & & \multicolumn{2}{|c|}{ Mutation } & \multirow[b]{2}{*}{$\begin{array}{c}\text { Total } \\
\mathrm{n}\end{array}$} & \multirow[b]{2}{*}{$\mathrm{P}$ value } \\
\hline & & No & Yes & & \\
\hline & & $\mathrm{n}$ & $\mathrm{n}$ & & \\
\hline \multirow[t]{2}{*}{ Phototype } & I / II & $41(80,4 \%)$ & $8(100 \%)$ & $49(83 \%)$ & 0.32 \\
\hline & III / IV & $10(19.6 \%)$ & $0(0 \%)$ & $10(17 \%)$ & \\
\hline \multirow[t]{2}{*}{ AMS } & No & $30(58.8 \%)$ & $6(75 \%)$ & $36(61 \%)$ & 0.26 \\
\hline & Yes & $21(41.2 \%)$ & $2(25 \%)$ & $23(39 \%)$ & \\
\hline \multirow[t]{3}{*}{ Eye color } & Blue & $9(17.5 \%)$ & $2(25 \%)$ & $11(19 \%)$ & 0.88 \\
\hline & Green & $15(29.5 \%)$ & $2(25 \%)$ & $17(29 \%)$ & \\
\hline & Brown/black & $27 \quad(53 \%)$ & $4(50 \%)$ & $31(52 \%)$ & \\
\hline \multirow[t]{3}{*}{ Hair color $^{1}$} & Red & $1 \quad(2 \%)$ & $0(0 \%)$ & $1(2 \%)$ & 0.35 \\
\hline & Blond & $25(49 \%)$ & $2(25 \%)$ & $27(46 \%)$ & \\
\hline & Brown & $25(49 \%)$ & $6(75 \%)$ & $31(52 \%)$ & \\
\hline \multirow[t]{2}{*}{ nevi count } & $0-50$ & $28(55 \%)$ & $6(75 \%)$ & $34(58 \%)$ & 0.33 \\
\hline & $\geq 50$ & $23(45 \%)$ & $2(25 \%)$ & $25(42 \%)$ & \\
\hline \multirow[t]{2}{*}{ Iris pigmantation } & No & $35(90 \%)$ & $4(50 \%)$ & $39(66 \%)$ & 0.73 \\
\hline & Yes & $16(80 \%)$ & $4(50 \%)$ & $20(34 \%)$ & \\
\hline \multirow[t]{2}{*}{ sunburn } & No & $14(70 \%)$ & $6(75 \%)$ & $20(34 \%)$ & 0.06 \\
\hline & Yes & $37(95 \%)$ & $2(25 \%)$ & $39(66 \%)$ & \\
\hline
\end{tabular}

${ }^{1}$ The red hair patient was excluded from this analyses

FMS: familial melanoma syndrome

Table 2. Clinical and molecular characterization of individuals carrying CDKN2A mutations, from FMS group

\begin{tabular}{|c|c|c|c|c|c|c|c|c|}
\hline \multirow{2}{*}{$\begin{array}{c}\text { Individual } \\
\text { (ID) }\end{array}$} & \multirow[t]{2}{*}{ Age(a) } & \multicolumn{2}{|c|}{ Melanomas } & \multirow{2}{*}{$\begin{array}{c}\text { Clinical Criteria } \\
(\text { FM/MPM })^{d}\end{array}$} & \multirow{2}{*}{$\begin{array}{l}C D K N 2 A \\
(p 14 / p 16)\end{array}$} & \multicolumn{2}{|c|}{ Mutation Description } & \multirow{2}{*}{ Gene Region } \\
\hline & & proband $^{b}$ & family $^{\mathrm{c}}$ & & & c.DNA & Aminoacid & \\
\hline 5 & 49 & 2 & 2 & $\mathrm{FM}+\mathrm{MPM}$ & p16 & c. $301 \mathrm{G}>\mathrm{T}$ & p.G101W & Exon 2 \\
\hline 6 & 48 & 2 & 2 & $\mathrm{FM}+\mathrm{MPM}$ & p16 & c. $142 \mathrm{C}>\mathrm{A}$ & p.P48T & Exon 2 \\
\hline 17 & 23 & 2 & 1 & $\mathrm{FM}+\mathrm{MPM}$ & pl6 & c. $-34 \mathrm{G}>\mathrm{T}$ & $\mathrm{n} / \mathrm{a}$ & Promoter \\
\hline 18 & 53 & 4 & 1 & $\mathrm{FM}+\mathrm{MPM}$ & pl6 & c. $-34 \mathrm{G}>\mathrm{T}$ & $\mathrm{n} / \mathrm{a}$ & Promoter \\
\hline 33 & 33 & 4 & 0 & MPM & pl6 & c. $142 \mathrm{C}>\mathrm{A}$ & p.P48T & Exon 2 \\
\hline 36 & 59 & 1 & 1 & FM & pl6 & c. $-34 \mathrm{G}>\mathrm{T}$ & $\mathrm{n} / \mathrm{a}$ & Promoter \\
\hline 44 & 39 & 1 & 3 & FM & pl6 & c. $142 \mathrm{C}>\mathrm{A}$ & p.P48T & Exon 2 \\
\hline 46 & 36 & 1 & 2 & FM & p16 & c.IVS-105G $>A$ & $\mathrm{n} / \mathrm{a}$ & Intron 2 \\
\hline
\end{tabular}

afirst melanoma, age of onset

bumber of melanoma cases

'number of relatives affected

${ }^{d}$ FM: familial melanoma; MPM - multiple primary melanoma

\section{Discussion}

Many studies about FMS have already been conducted around the world, especially in Europe and Australia. However, most of them were about germline mutations and polymorphism on CDKN2A gene, MC1R polymorphism and risk factors for CM development [21-25]. Few of them have focused on phenotype characterization within melanomaprone families. On Table 7, we gather some studies that described phenotypic features in melanoma patients, sporadic and/ or familial. There is no previous study comparing FMS versus SM including control group, regarding all the characteristics we have studied.

Thus, in this study we tried to find out if there is a specific phenotype for FMS population in Brazil and whether it differs or not from the other groups (SM and $\mathrm{HI}$ ).
We were able to see that many features that confer higher risk for melanoma development were prevalent on FMS patients.

For FMS group, our results regarding the presence of dark hair and eyes $(53 \%$ for both) are in accordance to previous studies [22,24,26]. About tan ability, an Italian and a Spanish study showed predominance of phototypes III and IV [24,26]. On the other hand, Yang XR et al. [27] found $85.6 \%$ of familial melanoma patients with pale/fair skin type, also observed in our study.

Our results agree with previous studies, which reported familial melanoma associated to younger age at diagnosis, increased nevi number and high density of freckles [26-28].

In the bivariate analyses, comparing the 3 groups, both the presence of atypical nevi and the AMS phenotype were prevalent on FMS group, 
Moredo LF (2020) Familial melanoma syndrome - phenotypic characterization and comparison with sporadic melanoma and healthy individuals - A Brazilian study

Table 3. The three groups analysed according to phenotipic features: Familial melanoma, Sporadic Melanoma and Healthy Individual

\begin{tabular}{|c|c|c|c|c|c|}
\hline Variables & Categories & FMS $(n=59)$ & SM $(n=54)$ & HI $(n=74)$ & P value \\
\hline \multirow{3}{*}{ Eye color } & Blue & $11(19 \%)$ & $06(11 \%)$ & $13(18 \%)$ & \multirow{3}{*}{0.236} \\
\hline & Green & $17(29 \%)$ & $13(24 \%)$ & $11(15 \%)$ & \\
\hline & Brown/black & $31(53 \%)$ & $35(65 \%)$ & $50(68 \%)$ & \\
\hline \multirow{2}{*}{ Hair color ${ }^{1}$} & Blond & $27(47 \%)$ & $20(38 \%)$ & $21(29 \%)$ & \multirow{2}{*}{0.109} \\
\hline & Brown/black & $31(53 \%)$ & $32(62 \%)$ & $52(71 \%)$ & \\
\hline \multirow{2}{*}{ Freckles in the lower arm } & $0-40$ & $48(81 \%)$ & $47 \quad(87 \%)$ & $71(96 \%)$ & \multirow{2}{*}{0.026} \\
\hline & $60-100$ & $11(19 \%)$ & $07 \quad(13 \%)$ & $03(04 \%)$ & \\
\hline \multirow{2}{*}{ Freckles in the back } & $0-40$ & $23(39 \%)$ & $26(48 \%)$ & $57 \quad(77 \%)$ & \multirow{2}{*}{$<0.001$} \\
\hline & $60-100$ & $36(61 \%)$ & $28(52 \%)$ & $17 \quad(23 \%)$ & \\
\hline \multirow{2}{*}{ Common nevi count } & $0-50$ & $34(58 \%)$ & $37(69 \%)$ & $66 \quad(89 \%)$ & \multirow{2}{*}{$<0.001$} \\
\hline & $\geq 50$ & $25(42 \%)$ & $17(31 \%)$ & $08 \quad(11 \%)$ & \\
\hline \multirow{2}{*}{ Iris pigmentation } & No & $39(66 \%)$ & $48 \quad(89 \%)$ & $61 \quad(82 \%)$ & \multirow[b]{2}{*}{0.008} \\
\hline & Yes & $20(34 \%)$ & $06(11 \%)$ & $13 \quad(18 \%)$ & \\
\hline \multirow{2}{*}{ Phototype } & $\mathrm{I} / \mathrm{II}$ & $49(83 \%)$ & $39(72 \%)$ & $31 \quad(42 \%)$ & \multirow{2}{*}{$<0.001$} \\
\hline & III/IV & $10(17 \%)$ & $15(28 \%)$ & $43 \quad(58 \%)$ & \\
\hline \multirow{2}{*}{ Atypical Nevi } & No & $37(63 \%)$ & $39(72 \%)$ & $64(86 \%)$ & \multirow{2}{*}{0.006} \\
\hline & Yes & $22(37 \%)$ & $15(28 \%)$ & $10(14 \%)$ & \\
\hline \multirow{2}{*}{ AMS } & No & $36(61 \%)$ & $52 \quad(96 \%)$ & $73 \quad(99 \%)$ & \multirow{2}{*}{$<0.001$} \\
\hline & Yes & $23(39 \%)$ & $2(4 \%)$ & $1 \quad(1 \%)$ & \\
\hline \multirow{2}{*}{ Sunburn } & No & $20(34 \%)$ & $09(17 \%)$ & $26(35 \%)$ & \multirow{2}{*}{0.05} \\
\hline & Yes & $39(66 \%)$ & $45(83 \%)$ & $48(65 \%)$ & \\
\hline
\end{tabular}

${ }^{1}$ The red hair patient was excluded from this analyses

AMS: atypical mole syndrome

Table 4. Familial Melanoma Syndrome versus Sporadic melanoma: phenotypic characteristics

\begin{tabular}{|c|c|c|c|c|}
\hline Variables & categories & $\begin{array}{c}\text { FMS } \\
(\mathrm{n}=59)\end{array}$ & $\begin{array}{c}\text { SM } \\
(n=54)\end{array}$ & $\mathbf{p}$ \\
\hline \multirow[t]{3}{*}{ Eye color } & Blue & $11(19 \%)$ & $6(11 \%)$ & \\
\hline & Green & $17(29 \%)$ & $13(24 \%)$ & 0.53 \\
\hline & Brown/black & $31(53 \%)$ & $35(65 \%)$ & \\
\hline \multirow[t]{2}{*}{ Hair color } & Blond & $27(46 \%)$ & $20(37 \%)$ & 0.39 \\
\hline & Brown/black & $31(52 \%)$ & $32(59 \%)$ & \\
\hline \multirow[t]{2}{*}{ Freckles in the lower arm } & $0-40$ & $48 \quad(81 \%)$ & $47(87 \%)$ & 0.34 \\
\hline & $60-100$ & $11(19 \%)$ & $7(13 \%)$ & \\
\hline \multirow[t]{2}{*}{ Freckles in the back } & $0-40$ & $23(39 \%)$ & $26(48 \%)$ & 0.6 \\
\hline & $60-100$ & $36(61 \%)$ & $28(52 \%)$ & \\
\hline \multirow[t]{2}{*}{ Common nevi count } & $0-50$ & $34(58 \%)$ & $37(69 \%)$ & 0.12 \\
\hline & $\geq 50$ & $25(42 \%)$ & $17(31 \%)$ & \\
\hline \multirow[t]{2}{*}{ Iris pigmentation } & No & $39(66 \%)$ & $48(89 \%)$ & 0.003 \\
\hline & Yes & $20(34 \%)$ & $6(11 \%)$ & \\
\hline \multirow[t]{2}{*}{ Phototype } & I and II & $49 \quad(83 \%)$ & $39(72 \%)$ & 0.11 \\
\hline & III and IV & $10(17 \%)$ & $15(28 \%)$ & \\
\hline Sunburn & No & $20(34 \%)$ & $9(17 \%)$ & 0.03 \\
\hline
\end{tabular}


Moredo LF (2020) Familial melanoma syndrome - phenotypic characterization and comparison with sporadic melanoma and healthy individuals - A Brazilian study

\begin{tabular}{|c|c|c|c|c|}
\hline & Yes & $39(66 \%)$ & $45(83 \%)$ & \\
\hline AMS & No & $36(61 \%)$ & $52(96 \%)$ & $<0.001$ \\
\hline & Yes & $23(39 \%)$ & $2(4 \%)$ & \\
\hline Atypical Nevi & No & $37(63 \%)$ & \multirow{2}{*}{\multicolumn{2}{|c|}{$\begin{array}{c}39(72 \%){ }_{(28 \%)}^{0.281} \\
15{ }^{2}\end{array}$}} \\
\hline & Yes & $22(37 \%)$ & & \\
\hline
\end{tabular}

AMS: Atypical mole syndrome

Table 5. Multinomial regression model- estimation of parameters

\begin{tabular}{|c|c|c|c|c|c|c|c|}
\hline \multirow{2}{*}{ Group } & \multirow{2}{*}{ Variable } & \multirow{2}{*}{ Estimate } & \multirow{2}{*}{ Standard error } & \multirow{2}{*}{ Odds ratio (O.R.) } & \multicolumn{2}{|c|}{$95 \%$ confidence interval for $\mathbf{O . R}$. } & \multirow{2}{*}{ p-value } \\
\hline & & & & & Lower & Upper & \\
\hline \multirow{4}{*}{ HI } & Intercept & 0.278 & 0.474 & & & & 0.557 \\
\hline & AMS (yes) & -1.229 & 1.258 & 0.293 & 0.025 & 3.443 & 0.329 \\
\hline & phototype (III-IV) & 1.162 & 0.406 & 3.195 & 1.443 & 7.075 & 0.004 \\
\hline & Sunburn (yes) & -0.568 & 0.471 & 0.567 & 0.225 & 1.427 & 0.228 \\
\hline \multirow{4}{*}{ FMS } & Intercept & 0.991 & 0.485 & & & & 0.041 \\
\hline & AMS (yes) & 3.253 & 0.826 & 25.865 & 5.123 & 130.592 & $<0.001$ \\
\hline & phototype (III-IV) & -1.336 & 0.572 & 0.263 & 0.086 & 0.807 & 0.020 \\
\hline & Sunburn (yes) & -1.506 & 0.528 & 0.222 & 0.079 & 0.624 & 0.004 \\
\hline
\end{tabular}

"Reference group is level: SM

HI: healthy individual; FMS: familial melanoma syndrome; AMS: atypical mole syndrome; SM: sporadic melanoma

Table 6. Estimated probabily for FMS based on multinomial regression

\begin{tabular}{|c|c|c|c|c|c|}
\hline \multirow{2}{*}{ AMS } & \multirow{2}{*}{ Phototype } & \multirow{2}{*}{ Sunburn history } & \multicolumn{3}{|c|}{ Estimated probability } \\
\hline & & & HI & SM & FMS \\
\hline 0 & I-II & 0 & 0.2634 & 0.1994 & 0.5372 \\
\hline 0 & I-II & 1 & 0.3190 & 0.4260 & 0.2550 \\
\hline 0 & III-IV & 0 & 0.7120 & 0.1690 & 0.1190 \\
\hline 0 & III-IV & 1 & 0.6740 & 0.2820 & 0.0440 \\
\hline 1 & I-II & 0 & 0.0054 & 0.0141 & 0.9805 \\
\hline 1 & I-II & 1 & 0.0130 & 0.0600 & 0.9270 \\
\hline 1 & III-IV & 0 & 0.0601 & 0.0487 & 0.8912 \\
\hline 1 & III-IV & 1 & 0.1210 & 0.1740 & 0.7050 \\
\hline
\end{tabular}

HI: Healthy individual; FMS: Familial melanoma syndrome; AMS: Atypical mole syndrome; SM: Sporadic

Table 7. The main phenotypic characteristics analysed in related articles, regarding individuals with cutaneous melanoma

\begin{tabular}{|c|c|c|c|c|c|c|c|c|c|}
\hline First author, year, country & \# of patients & \# of groups compared & $\begin{array}{c}\text { FMS } \\
\text { population }\end{array}$ & EC & $\mathrm{HC}$ & PhT & AN & NC & FR \\
\hline Bakos L, 2002, Brazil (19) & 309 & 2- $\mathrm{SM} /$ controls & No & $\mathrm{X}$ & $\mathrm{X}$ & $\mathrm{X}$ & $\mathrm{X}$ & $\mathrm{X}$ & $\mathrm{X}$ \\
\hline Goldstein AM,2007, USA (21) & $\sim 42$ & $\begin{array}{l}\text { 4- according to home } \\
\text { country }\end{array}$ & Yes & $\mathrm{X}$ & $\mathrm{X}$ & $\mathrm{X}$ & $\mathrm{X}$ & $\mathrm{X}$ & $\mathrm{X}$ \\
\hline P Ashton-Prolla, 2008, Brazil (29) & 30 & & Yes & & & $\mathrm{X}$ & & & \\
\hline F Cuéllar, 2009, Spain (30) & 9 & & Yes & $\mathrm{X}$ & $\mathrm{X}$ & $\mathrm{X}$ & & & \\
\hline L Borges, 2009, Uruguai (22) & 13 & & Yes & $\mathrm{X}$ & $\mathrm{X}$ & $\mathrm{X}$ & $\mathrm{X}$ & & \\
\hline Yang XR, 2010, USA* (27) & 53 families & 2- FMS/ controls & Yes & $\mathrm{X}$ & $\mathrm{X}$ & $\mathrm{X}$ & & $\mathrm{X}$ & $\mathrm{X}$ \\
\hline Pedace L,2011, Italy (24) & 100 & $\begin{array}{l}\text { 2- FMS wild-type/ } \\
\text { mutated }\end{array}$ & Yes & $\mathrm{X}$ & $\mathrm{X}$ & $\mathrm{X}$ & & $\mathrm{X}$ & \\
\hline MM Peña-Vilabelda, 2014, Spain (31) & 1044 & & Not specifically & $\mathrm{X}$ & $\mathrm{X}$ & $\mathrm{X}$ & $\mathrm{X}$ & $\mathrm{X}$ & $\mathrm{X}$ \\
\hline M C Fargnoli, 2014, Italy (32) & 62 & & No & $\mathrm{X}$ & $\mathrm{X}$ & $\mathrm{X}$ & & & \\
\hline P Aguilera, 2014, Spain (26) & 189 & 2-FMS/ SM & Yes & $\mathrm{X}$ & $\mathrm{X}$ & $\mathrm{X}$ & & $\mathrm{X}$ & \\
\hline E Pasquali, 2015, Italy** (9) & 17 studies & $\begin{array}{l}\text { Acoording to MC1R } \\
\text { variant }\end{array}$ & No & & $\mathrm{X}$ & $\mathrm{X}$ & & & $\mathrm{X}$ \\
\hline
\end{tabular}

References in brackets ()

"controls were unaffected family members and genetically unrelated spouses

"pooled-analysis

SM: sporadic melanoma; FMS: familial melanoma syndrome; EC: eye color; HC: hair color, PhT: phototype; AN: presence of atypical nevi; NC: nevi count; FR: freckles; MC1R: melanocortin 1 receptor 
showing the importance of this phenotype on determining melanoma risk.

However, we were not able to find association between these characteristics and CDKN2A mutation, maybe due to the limited number of positive patients [29-32].

Among the most prevalent characteristics found in FMS group, AMS phenotype, phototype I or II and history of sunburn were the ones that allowed us to determined the estimated probability for FM patients, by multinomial regression model. The presence of AMS phenotype and phototype I or II determined the highest probability for FMS. History of sunburn, even though determining high probability when associated with the other two characteristics, whenever present determines a lower probability for FMS compared to its absence. It might suggest that this risk factor plays an important role, not only as a risk marker but also as a keypoint in melanomagenesis.

\section{Conclusion}

Our study suggests that when facing a cutaneous melanoma patient with AMS phenotype and phototype I or II, we might investigate properly cancer family history. This work also emphasizes the importance of sunburn as a risk factor for sporadic melanoma.

\section{Acknowledgments}

We gratefully thank Susana Puig for the assistance, helpful comments and suggestions. The authors are also grateful to Aline Damascena and Vinícius Calsavara for the statistical analysis. This work would not have been possible without the patients from GenoMEL consortium (São Paulo) and other patients of skin cancer department, especially from the familial melanoma clinic from A C Camargo Cancer Center. It was granted by FAPESP (Foundation for Research Support -São Paulo State).

\section{Conflict of interest}

The authors declare no conflicts of interest.

\section{References}

1. Pho L, Grossman D, Leachman SA (2006) Melanoma genetics: A review of genetic factors and clinical phenotypes in familial melanoma. Curr Opin Oncol 18: 173-179. [Crossref]

2. Santillan AA, Cherpelis BS, Glass LF, Sondak VK (2009) Management of familial melanoma and nonmelanoma skin cancer syndromes. Surg Oncol Clin N Am 18: 73-98.

3. Gabree M, Seidel M (2012) Genetic testing by cancer site: skin. Cancer J 18: 372-380.

4. Potrony M, Badenas C, Aguilera P, Puig-Butille JA, Carrera C (2015) Update in genetic susceptibility in melanoma. Ann Transl Med 3: 210. [Crossref]

5. Bishop DT, Demenais F, Goldstein AM (2002) Geographical variation in the penetrance of CDKN2A mutations for melanoma. J Natl Cancer Inst 94: 894-903.

6. Chaudru V, Chompret A, Bressac-de Paillerets B, Spatz A, Avril MF (2004) Influence of genes, nevi, and sun sensitivity on melanoma risk in a family sample unselected by family history and in melanoma-prone families. J Natl Cancer Inst 96: 785-795.

7. Hansen CB, Wadge LM, Lowstuter K, Boucher K, Leachman SA (2004) Clinical germline genetic testing for melanoma. Lancet Oncol 5: 314-319.

8. Ibarrola-Villava M, Fernandez LP, Pita G, Bravo J, Floristan U (2010) Genetic analysis of three important genes in pigmentation and melanoma susceptibility: CDKN2A, MC1R and HERC2/OCA2. Exp Dermatol 19: 836-844.

9. Pasquali E, García-Borrón JC, Fargnoli MC, Gandini S, Maisonneuve P (2015) M-SKIP Study Group. MC1R variants increased the risk of sporadic cutaneous melanoma in darker-pigmented Caucasians: a pooled-analysis from the M-SKIP project. Int $J$ Cancer 136: 618-631.
10. Márquez-Rodas I, Martín González M, Nagore E, Gómez-Fernández C, AvilésIzquierdo JA (2015) Spanish multidisciplinary group of melanoma (GEM). Frequency and characteristics of familial melanoma in Spain: the FAM-GEM-1 Study. PLoS One 10: $\mathrm{e} 0124239$.

11. Dawkins R (1999) The Extended Phenotype: the long reach of the gene.

12. Johannsen W (1911) The genotype conception of heredity. American Naturalist 45: 129-159.

13. Goldstein AM, Chaudru V, Ghiorzo P, Badenas C, Malvehy J (2007) Cutaneous phenotype and MC1R variants as modifying factors for the development of melanoma in CDKN2A G101W mutation carriers from 4 countries. Int J Cancer 121: 825-831. [Crossref]

14. Newton JA, Bataille V, Griffiths K, Squire JM, Sasieni P (1993) How common is the atypical mole syndrome phenotype in apparently sporadic melanoma? J Am Acad Dermatol 29: 989-996.

15. Slade J, Marghoob AA, Salopek TG, Rigel DS, Kopf AW (1995) A typical mole syndrome: risk factor for cutaneous malignant melanoma and implications for management. J Am Acad Dermatol 32: 479-494.

16. Bishop JA, Wachsmuth RC, Harland M, Bataille V, Pinney E (2000) Genotype/ phenotype and penetrance studies in melanoma families with germline CDKN2A mutations. J Invest Dermatol 114: 28-233.

17. Silva JH, Sá BC, Avila AL, Landman G, Duprat Neto JP (2011) Atypical mole syndrome and dysplastic nevi: identification of populations at risk for developing melanoma review article. Clinics (Sao Paulo) 66: 493-499.

18. de Ávila AL, Krepischi AC, Moredo LF, Aguiar TF, da Silva FC (2014) Germline CDKN2A mutations in Brazilian patients of hereditary cutaneous melanoma. Fam Cancer 13: 645-649.

19. Bakos L, Wagner M, Bakos RM, Leite CS, Sperhacke CL (2002) Sunburn, sunscreens, and phenotypes: some risk factors for cutaneous melanoma in southern Brazil. Int $J$ Dermatol 41: 557-562.

20. Veierød MB, Weiderpass E, Thörn M, Hansson J, Lund E (2003) A prospective study of pigmentation, sun exposure, and risk of cutaneous malignant melanoma in women. J Natl Cancer Inst 95: 1530-1538.

21. Goldstein AM, Chan M, Harland M (2007) Features associated with germline CDKN2A mutations: a GenoMEL study of melanoma-prone families from three continents. $J$ Med Genet 44: 99-106.

22. Larre Borges A, Cuéllar F, Puig-Butillé JA, Scarone M, Delgado L (2009) CDKN2A mutations in melanoma families from Uruguay. Br J Dermatol 161: 536-541. [Crossref]

23. Bakos RM, Besch R, Zoratto GG, Godinho JM, Mazzotti NG (2011) The CDKN2A p.A148T variant is associated with cutaneous melanoma in Southern Brazil. Exp Dermatol 20: 890-893.

24. Pedace L, De Simone P, Castori M (2011) Clinical features predicting identification of CDKN2A mutations in Italian patients with familial cutaneous melanoma. Cancer Epidemiol 35: 116-120.

25. Maubec E, Chaudru V, Mohamdi H, Blondel C, Margaritte-Jeannin P, et al. (2012) Familial melanoma: clinical factors associated with germline CDKN2A mutations according to the number of patients affected by melanoma in a family. $J$ Am Acad Dermatol 67: 1257-1264.

26. Aguilera P, Malvehy J, Carrera C, Palou J, Puig-Butillé JA (2014) Clinical and histopathological characteristics between familial and sporadic melanoma in Barcelona, Spain. J Clin Exp Dermatol Res 5: 231.

27. Yang XR, Liang X, Pfeiffer RM, Wheeler W, Maeder D, et al. (2010) Associations of 9 p21 variants with cutaneous malignant melanoma, nevi, and pigmentation phenotypes in melanoma-prone families with and without CDKN2A mutations. Fam Cancer 9: 625-633.

28. Watts CG, Madronio C, Morton RL, Goumas C, Armstrong BK (2017) Clinical features associated with individuals at higher risk of melanoma: A Population-Based Study. JAMA Dermatol 153: 23-29.

29. Ashton-Prolla P, Bakos L, Junqueira G Jr, Giugliani R, Azevedo SJ (2008) Clinical and molecular characterization of patients at risk for hereditary melanoma in southern Brazil. J Invest Dermatol 128: 421-425.

30. Cuéllar F, Puig S, Kolm I, Puig-Butille J, Zaballos P (2009) Dermoscopic features of melanomas associated with MC1R variants in Spanish CDKN2A mutation carriers. $\mathrm{Br}$ J Dermatol 160: 48-53. 
Moredo LF (2020) Familial melanoma syndrome - phenotypic characterization and comparison with sporadic melanoma and healthy individuals - A Brazilian study

31. Peña-Vilabelda MM, García-Casado Z, Requena C, Traves V, López-Guerrero JA (2014) Clinical characteristics of patients with cutaneous melanoma according to variants in the melanocortin 1 receptor gene. Actas Dermosifiliogr 105: 159-171.
32. Fargnoli MC, Sera F, Suppa M, Piccolo D, Landi MT (2014) Dermoscopic features of cutaneous melanoma are associated with clinical characteristics of patients and tumours and with MC1R genotype. J Eur Acad Dermatol Venereol 28: 1768-1775. [Crossref]

Copyright: (C2020 Moredo LF. This is an open-access article distributed under the terms of the Creative Commons Attribution License, which permits unrestricted use, distribution, and reproduction in any medium, provided the original author and source are credited. 